\title{
Torcedores organizados: \\ enigma como contrapeso ao fantasma da razão esclarecida
}

\author{
Barras Bravas: \\ enigma como contrapeso al fantasma de la razón esclarecida
}

Football supporters groups:
enigma as counterweight to the ghost of the enlightened reason

Gustavo Coelho'

\author{
Palavras chave: \\ Estudos da subjetividade \\ Antropologia \\ Juventude \\ Epistemologia \\ Imaginário
}

\section{Resumo:}

A partir de alguns relatos etnográficos conduzidos no seio de torcidas organizadas de futebol, assim como através de imagens que compõem seus cotidianos,materiaisem cruzamento teórico com autores como Simmel, Gumbrecht, Mauss, Hubert, Clastres, Durand, Durkheim, Maffesoli e alguma influência na filosofia de Nietzsche,este artigo esmiúça esse universo, particularmente seus paroxismos intimamente relacionados à temática do Mal. Desses cruzos entre empiria e teoria, então, sugerimos que universos jovens e populares de nossas cidades, mesmo sendo constantemente reduzidos sob a máquina do discurso determinante e criminalizador, podem guardar em seus complexos cotidianos, ricos reservatórios de formas de viver, de imagens, de narrativas, de rituais, de experiências estéticas, de epifanias, que operam como "tecnologias" encantadas na defesa e garantia cotidiana da manutenção de uma zona subjetiva que celebra o indeterminado, o enigma, em contrapeso ao fantasma do desencantamento pela determinação racionalista, esclarecida. 


\section{Resumen:}

A partir de algunos relatos etnográficos conducidos en el seno de barras bravas de fútbol, así como a través de imágenes que componen sus cotidianos, materiales en cruzamiento teórico con autores como Simmel, Gumbrecht, Mauss, Hubert, Clastres, Durand, Durkheim, Maffesoli y alguna influencia en la filosofía de Nietzsche, este artículo detalla este universo, particularmente sus paroxismos íntimamente relacionados a la temática del Mal. De eses cruzamientos entre empírea y teoría, entonces, proponemos que universos jóvenes y populares de nuestras ciudades, incluso siendo constantemente reducidos bajo la máquina del discurso determinante y criminalizador, pueden guardar en sus complejos cotidianos ricos reservatorios de formas de vivir, de imágenes, de narrativas, de rituales, de experiencias estéticas, de epifanías, que operan como "tecnologías" encantadas en la defensa y garantía cotidiana da manutención de una zona subjetiva que celebra lo indeterminado, o enigma, en contrapeso al fantasma del desencantamiento por la determinación racionalista, esclarecida.

\section{Palabras clave:}

Estudios da subjetividad

Antropologia

Juventud

Epistemologia

Imaginario

\section{Keywords:}

\section{Subjectivity}

Antropology

Youth

Epistemology

Imaginary

\section{Abstract:}

From some ethnographic reports conducted within football supporters groups, as well as through images from their everyday lives, materials in theoretical intersection with authors as Simmel, Gumbrecht, Mauss, Hubert, Clastres, Durand, Durkheim, Maffesoli and some influence on the philosophy of Nietzsche, this article explores this universe, particularly its paroxysms closely related to the theme of Evil. From these crosses between empiricism and theory, then, we suggest that young and popular universes of our cities, despite being constantly reduced under the determinant and criminalizing speech machine, can save in their complex everyday lives, rich reservoirs of ways of living, images, narratives, rituals, aesthetic experiences, epiphanies, operating as enchanted "technologies" in defense and guarantee of a subjective zone that celebrates the indeterminate, the enigma, in counterweight to the ghost of disenchantment by the rationalist and enlightened determination. 


\section{Torcedores organizados: enigma como contrapeso ao fantasma da razão esclarecida}

Era jogo do Fluminense contra o Friburguense pela primeira rodada do Campeonato Carioca de 2012 no Estádio de Moça Bonita em Bangu". Dudu, da Torcida Organizada Young Flu, que foi meu principal auxiliar na pesquisa, definitivo em especial para uma entrada bem feita no campo, apresentou-me a um torcedor já antigo da torcida que naquele momento expunha para venda algumas camisas-pirata do Fluminense na praça em frente ao Estádio.

-Esse aqui, é o Xoxó, com ele você vai ouvir muita história! - apresentou-me Dudu.

- Ah se você quer ouvir história, pega meu telefone que nessa torcida eu já vivi tudo, tudo mesmo, você nem imagina. Olha aqui - disse ele arregaçando uma das mangas e exibindo seu ombro - essa tatuagem aqui eu fiz na cadeia.

Era uma tatuagem com a inscrição Young Flu, bem pequena, feita provavelmente com tinta de caneta mesmo, como é comum em tatuagens feitas em presídio, resultando em uma cor gasta meio esverdeada e em letras não alinhadas, o que corrobora a construção do imaginário do desgaste e da ruína como índices corporais, e que carregam justamente em sua degradação, os indicativos da experiência vivida. Um imaginário que fora ainda reafirmado pela maneira como Dudu o apresentou, não por acaso seguido prontamente da exibição da tatuagem como cartão de visitas naquele nosso primeiro contato. Ao exibi-la, ele ainda bateu três vezes uma de suas mãos com relativa força sobre o ombro tatuado, o que fazia vibrar não somente o ombro batido, mas o arsenal memorial que aquele corpo carregava. A isso, ele seguiu dizendo:
- A Young Flu é a minha vida! Para você ter uma ideia, eu coloquei Young Flu nos nomes dos meus filhos.

- Sério? Como assim?

-É sério, posso te mostrar as identidades deles, o mais novo é Marcos Young Flu e a menina é Mariana Young Flu. Se você quiser, me liga e a gente marca de conversar, é muita história.

Diante do baixo conhecimento memorial que em boa parte dos casos temos de nossos próprios nomes de família, cuja ancestralidade, por mais que a carreguemos, muitas vezes segue desconhecida durante toda nossa vida, esse senhor parece ter se dado conta de que o elemento memorial que constitui com mais força as bases de sentido de sua vida, ou ainda, aquilo que melhor lhe põe em contato com o mundo e que encheu seu reservatório de histórias, é justamente sua longa e intensa vivência na Young Flu. Sendo assim, ainda que tal batismo de seus filhos soe, à primeira vista, como loucura, ele possui o mesmo sentido que qualquer outro sobrenome de família, ou seja, exprime a comum vontade de que uma matriz memorial não seja esquecida, abrindo caminho, portanto, à continuidade de determinada herança cultural, de uma espécie de segredo passado pelo nome aos seus descendentes.

Outro ponto que me chamou atenção nessas nossas primeiras palavras, menos anedótico do que este último, porém mais significativo ao que nos importa nesse artigo, foi o fato de ele ter prontamente revelado sem muita cerimônia, seu passado como presidiário. Tal informação, parecia ter-me sido passada como mero fato histórico, dito aparentemente de maneira despretensiosa, ao final de um frase, descentralizada, deixando em segundo plano aquilo que agora considero sua função primordial, atuante menos conscientemente que inconscientemente. Primeiramente, ter estado preso assume nessa situação, uma função somente positiva, bem diferente da negativação comum às 
durezas enfrentadas por quem carrega esse passado na sociedade em geral. Cabe então a pergunta: do que se trata tal positividade nesse cenário particular? Sugiro, para começarmos a refletir sobre isso, pensarmos no aspecto ambivalente que a vida em presídio assume no imaginário social, em geral mais ou menos compartilhado. Por um lado, um lugar que representa o fim da liberdade, o encarceramento total e que, portanto, age como fantasma ameaçador coletivo a fim de agirmos de tal maneira que possamos evitar sermos levado a esse lugar. No entanto, por outro lado, a própria dureza de seus muros, o próprio rigor nas trancas de suas celas, também aviva a curiosidade geral sobre o seu cotidiano carregado de segredos, reforçados ainda pela também paradoxal sedução que nos causa essa comum sensação de liberdade atrelada ao vitalismo de intensidades e irresponsabilidades intimamente relacionado ao imaginário da vida do crime - fator amplamente utilizado nos romances, policiais ou não, no teatro, no cinema e claro, fator também de alta fertilidade no seio de diversas culturas jovens. É, no entanto, o conceito de "enigma" que acredito seja o mais determinante ao que desejo desenvolver aqui. Afinal, tanto a imagem da cela bem trancada, serve à manutenção desse enigma, como também a atração, própria de tal sedução proibida, assume a mesma função nessa proteção do enigma.

Georg Simmel (2010)"II chegou a brevemente desenvolver a função sociológica que o segredo assume nos rituais, no cotidiano, nos laços sociais, na mútua solidariedade a fim de produzir tanto os fatores de coesão quanto os de exclusão no seio de sociedades secretas, mas que talvez, de maneira menos reforçada, estejam também em funcionamento em todo tipo de agrupamento, mesmo nos mais efêmeros. Como pretendo complexificar o conceito desenvolvido de maneira um tanto ligeira sob a alcunha de "segredo" por Simmel, nele restrito a esse papel sociológico estrutural, decidi pelo uso de uma outra palavra que poderia até ser- vir de sinônimo a "segredo", mas que a meu ver tem maior peso - "enigma". Se "segredo" transmite a ideia de algo conhecido por um grupo de pessoas que pode, mediante algumas manobras e intenções, revelá-lo ou não a outras, podendo então constituir elemento de posse, sendo também algo de conteúdo definido, capaz de ser "esclarecido" com uma simples vontade de seu proprietário, e cujo acesso sanaria em definitivo uma curiosidade, o "enigma" pode supor uma insolubilidade patente, que é bem o caso do conceito que pretendo desenvolver neste artigo. Em outras palavras, para somente introduzir momentaneamente o que está em jogo, ser- Ihe apresentado não leva a possuí-lo, já que por natureza ele é incapturável, transborda e resiste diante de qualquer tentativa de definição; é mais um contato de comunhão que de controle, mais adentrar numa vibração dinâmica impedindo qualquer fixação do que a oferta de um domínio, é lançar-se num "devir-ilimitado" que opõe obstáculo a qualquer possessão da vida.

Por ora, retomemos alguma empiria. Os grupos de jovens que estudo acabam compartilhando uma série de características similares às das sociedades secretas, o que fica evidente em suas frequentes suspeitas quanto ao meu trabalho, especialmente quando encontrava jovens ainda não conhecidos em minha experiência de campo. Eu não compunha ainda seu cotidiano, não havia, então, estado ritualisticamente nem próximo do seu enigma e, portanto, havia sobre mim uma espécie de local de fronteira, onde a gestão mais rigorosa desse enigma assumia um papel fundamental. Por exemplo, em Paris ${ }^{\mathrm{IV}}$, quando conversava com um jovem torcedor de 27 anos, negro e que também já estivera preso durante dois anos, ao ser perguntado sobre uma briga que havia acontecido algumas semanas antes na Praça da Bastilha contra torcedores do Zagreb, time da Croácia, ele respondeu em tom de voz bem baixo, parecendo preocupar-se com quem eu realmente era e com quem, por azar, pudesse estar 
por perto: "Não, sobre isso eu não falo." - o que eu ouvi como sendo "sobre isso eu não falo com você", afinal, diante da importância do episódio, era óbvio que naquela semana ele tinha sim falado sobre isso por diversas vezes com seus companheiros.

Daí, portanto, que para esse tipo de pesquisa, a qualidade está intimamente ligada à presença empírica por longa duração do pesquisador nos locais de socialização, ao chão do cotidiano, especialmente naqueles onde a segurança de si poderá estar notadamente em risco, ou seja, onde a condição de "estar junto", ou "no bonde" com eles, opere uma suficiente repressão da posição destacada de "pesquisador", possibilitando algum nível de aglutinação, embora não total, para que justamente através dessa flexibilização da sua "posição", possam passar doses desse enigma. Talvez assim, pouco a pouco, ao miúdo, de segredo em segredo (e agora são mesmo segredos) como esse que o parisiense recusou me contar, você possa ir paulatinamente "sentindo" o enigma. Em resumo, o "estar junto" tão recorrente na obra de Maffesoli, aqui não é somente uma expressão que sintetiza uma tendência de nossa época de justaposições em oposição à modernidade divisora, mas também uma urgência metodológica. Somente a análise esfriada e posicionada subjetivamente no exterior, "acima" do vivido, de onde se "fala" dele, que o "transcreve" sem se "inscrever", funcionando na lógica "sujeito e predicado", e de lá operando pela expressão de certezas, cujo tipo por excelência é um jornalismo que dificilmente permite expressar dúvidas sobre o que acabara de ver pela primeira vez, não dá mais conta. É justamente, então, quando se pensa, dotado de uma qualidade moral superior, ter acessado determinado enigma e logo imediatamente, "ao vivo", o "desvelado", dado a ele uma expressão final, uma "informação", aí está dada, então, a forma de seu mais baixo nível de compreensão. É, portanto, a crença na transparência do "desvelado", o estado mais "vedado" da "velação", para usarmos termos heideggerianos (2010).
Como bem disse Simmel (2010, p. 388), "a sociedade secreta compensa ainda o momento de exclusão próprio de todo segredo". Um segredo, portanto, é elemento que por um lado pode isolar aquele que o conhece, mas que encontra na comunidade sua compensação, Ihe permitindo um paradoxo fundamental, o de continuar sendo segredo ao mesmo tempo em que é compartilhado por alguns, o que Simmel (2010, p. 388-389) bem resumiu assim: "não é então contraditório que o segredo seja tanto favorecido quanto destruído pela socialização". Já o enigma, forma mais desenvolvida do segredo, poderíamos dizer, justamente pois, pela socialização conduzida na própria continuidade da convivência, sendo reforçado por rituais de iniciação e de passagem, passa a ser sentido não em seu conteúdo, uma vez que não o possui em limites cognitivamente discerníveis, o que o igualaria ao destrutível segredo, mas, em sua forma, em seu modo de inscrição, traz à frente da cena o corpo, os humores, a experiência estética, como locais por onde encontra boa condutibilidade, necessitando para isso, portanto, da fissura das barreiras do monopólio da racionalidade cognitivo-instrumental (SANTOS, 2011) concentrada no indivíduo, as quais, se permanecessem bem fincadas, emperrariam sua circulação. Assim, o enigma garante sua indestrutibilidade, garante sua insolubilidade, já que não possui valor de dureza, não se estabelecendo em parte alguma mesmo estando por todo lado, inclusive nos pequenos segredos aqui e ali revelados. No entanto, para entender o que quero dizer, faz-se necessário compreender também a dimensão formal do segredo, o qual contém sim um conteúdo que pode ser contado, diferentemente do enigma, mas tem sua importância não somente no repertório desse contado possível, tendo-a também e principalmente na gestão econômica feita por aqueles que o possuem, em sua gradativa e seletiva contação. No mesmo sentido, Simmel (2010, p. 394) também disse, "o pathos do segredo, que é sempre perceptível e que se deve sempre preservar, dá 
ao laço formal ao qual ele está ligado, uma importância superior àquela do conteúdo."

Trata-se de um papel importante que assume no fortalecimento dos elãs sociais, nas narrativas que vão por esse processo sendo aqui e ali compartilhadas, assim compondo um manancial movente de forte capacidade agregadora, já que nesse universo, "ter histórias" é análogo a "ter marcas", a "ter vivências", e portanto, ser voz sempre convocada a mais uma contação. Em outras palavras e tentando apontar melhor a diferença entre segredo e enigma, a expressão "essa tatuagem eu fiz na cadeia", seguida da afirmação de que possui muita história para contar, quer nas entrelinhas dizer "guardo comigo um vasto repertório de histórias secretas que é preciso você ouvir para entrar em contato com esse nosso mundo", ou seja, ele estaria disponível a me ofertar alguns segredos, certamente motivado por eu ter sido apresentado a ele por um outro integrante, também experiente e também fonte acumulada de vasto repertório de histórias, o Dudu, disponibilidade imediata que muito provavelmente não aconteceria se eu 0 abordasse como um absoluto desconhecido, determinantemente destacado de seu cotidiano, ou seja, conduzido em minha totalidade pela racionalidade cognitivo-instrumental não implicada, fora "de todo rito".

Continuando, então, no que há nas entrelinhas desse encontro, "em todo caso, a razão porque fazemos essas loucuras, não tem explicação", e aqui sente-se o enigma, sempre aparecendo assim, escondido numa negação, forma única que pode "aparecer", "devir-louco" para usarmos expressão deleuziana (2011), limite instransponível à estreiteza de nossa linguagem viciada na instrumentação de objetivos informativos e transparentes. O segredo, portanto, afirma-se numa afirmação, enquanto que o enigma só pode afirmar-se negando, em função da ausência patente de conteúdo enunciável que o caracterize, estando então em estado de invisibilidade mesmo que sentido por todo lado, inclusive nos segredos.

Tal característica formal do segredo no jogo social lhe confere uma dimensão muito mais ampla aproximando-o então do enigma, já que não se trata, portanto, de simplesmente descobrir alguma coisa que Ihe será finalmente mostrada, o que seria conferir ao conteúdo uma superioridade. O segredo, então, requer um cuidado, ou seja, não pode acontecer sem que seu conteúdo seja bem guardado e mostrado somente após longo e fino esforço na manutenção temporária de seu desconhecimento, cuidado de cujo rigor depende a magicidade do jogo "esconder x mostrar", definitivo à intensidade que se experimenta no último momento. Perceber sua ação formal, então, é dar atenção à sua dimensão inconsciente, aos seus efeitos invisíveis, ao enigma que esse manejo torna presente sem que no entanto seja capturado. Em outras palavras, trata-se de, aos poucos, tanto pelos rituais mais bem formalizados, quanto pelos quase imperceptíveis pequenos rituais do cotidiano, perceber tanto as transformações corporais e psíquicas em curso nos gestos, nas maneiras de dizer, nos valores compartilhados, nas imagens oferecidas, nos traços, em suma, em seus impactos formais, esse mistério inapreensível do enigma que tem no segredo apenas uma de suas variantes e que nutre uma espécie de intriga popular dissimulada, escorregadia, insubordinada no impedimento da vitória da maquinaria normativa cognitivo-instrumental empenhada na fixação das suas subjetividades. O enigma, então, como arma negativa à opressão epistemológica colonizadora regida pela racionalidade de tipo instrumental, como esquema que embaralha e impede a instalação plena de qualquer engenharia epistêmica empenhada no interrompimento do dinamismo vital pela instalação de uma ordem estabelecida imobilizadora, movimento de resistência portanto. Voltando, então, a 
Simmel, nesse trecho ele parece aproximar o que chama de segredo, da noção de "enigma" que aqui desenvolvo:

um fato sociológico primário, uma certa maneira de estar junto, uma coloração, uma qualidade formal das relações, que determinam, numa ação recíproca diretamente ou indiretamente com os outros, os hábitos do membro do grupo ou do próprio grupo. (SIMMEL, 2010, p. 393)

Penso que em diversos momentos da etnografia base a este artigo, podemos perceber a circulação desses segredos, sentindo a riqueza do repertório desses jovens. No entanto, como já dei a entender, há uma diferença de qualidade relativa à variação da intensidade de suas doses, estando ao que me parece, o enigma mais exposto pelo embaçamento promovido na sublime sensação oferecida quando das doses mais intensas. Com isso quero dizer que há uma evidente injeção de vitalismo no ambiente e nos corpos envolvidos, quando frequentemente põem em cena o que há de mais bizarro, escatológico, absurdo, bruto, surreal, violento, tenso, arriscado, portanto Mal, seja no momento mesmo que se vive um episódio desse tipo, seja quando se está compartilhando alguma memória vivida. Em outros termos, ter acesso à história é acessar um segredo, mas é no absurdo surrealista que força a barra da inexplicabilidade, que põe a carga no que transborda a normatividade, deixando o fundamental paradoxo acontecer, que então nos é oferecido o enigma ofuscado por ele mesmo. Para pensar um pouco o papel antropológico dessas intensidades e seus efeitos no imaginário, vamos a algumas situações, tanto vividas por mim durante a pesquisa etnográfica, quanto que me foram contadas por alguns dos praticantes.

Voltando de um jogo do Fluminense contra a Ponte Preta em Campinas, já era tarde da noite no meio da estrada, em algum ponto próximo à divisa de São Paulo com o Rio de Janeiro, Xoxó, o mesmo da tatuagem, estava de pé no corredor do ônibus recontando suas histórias.

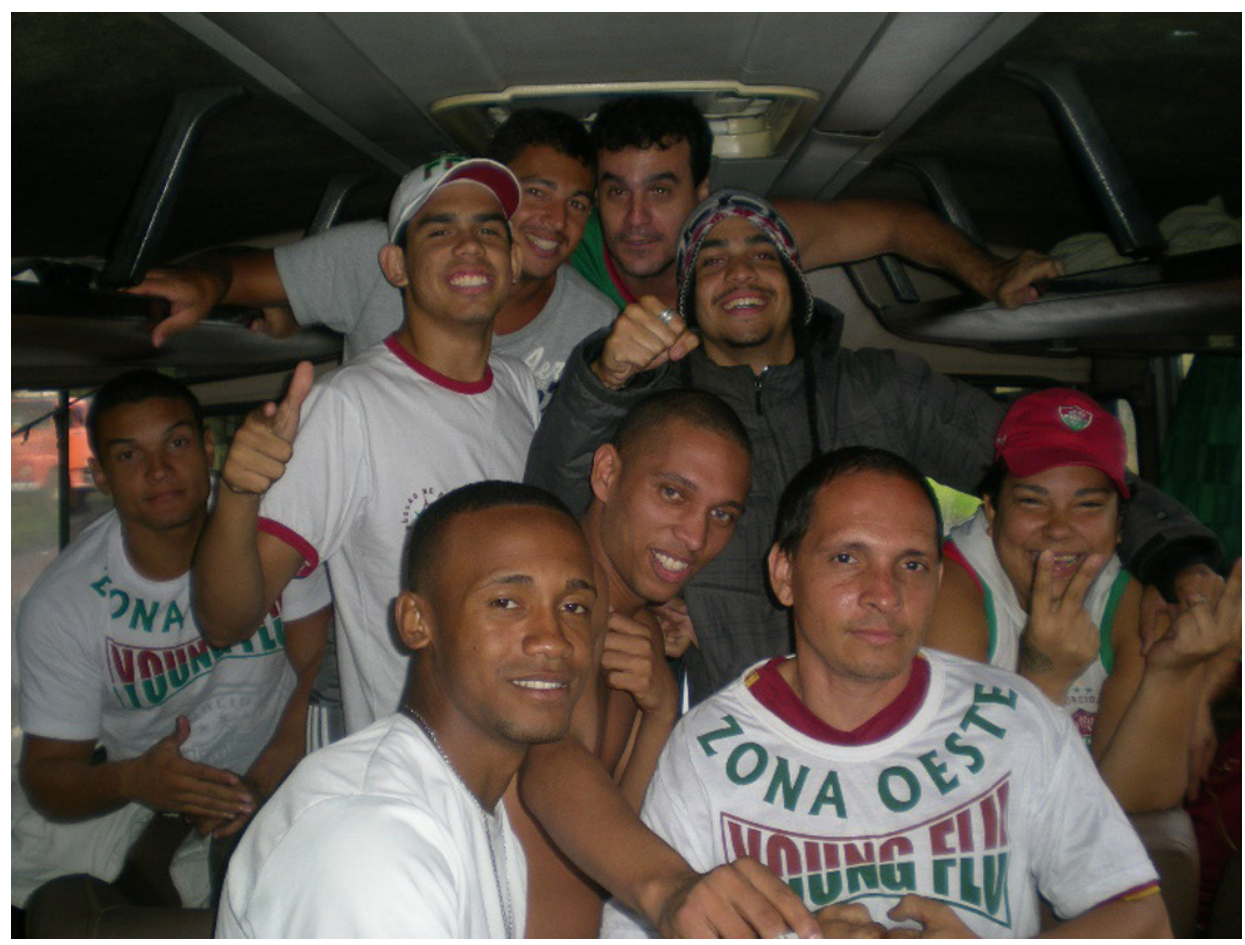

Fig. 1: Torcedores na caravana da Young Flu 
- Meu irmão, hoje é lazer isso aqui rapaz. Quem se lembra do Renê Paraíba? E o William, porra, hoje é lazer a Young cara. A gente ia para o jogo, chegava machucado e voltava machucado só de apanhar dentro do ônibus, nem precisava ter porrada com outra torcida. O "Passa Fome" batia igual um caralho! O Carlinhos Capeta da bateria, ele te batia de maceta! Renê Paraíba te dava era chute! Ele te pressionava... "Escala o time! Quem vai jogar hoje?" Porra, lembra o "Pé na Cova"? Porra... e o falecido, como se chamava mesmo?... E aqueles dois lá de Piedade... O Donty e o Dentinho, vai tomar no cu, porra maluco, caralho! "Escala o Time! Canta o Hino! Que dia foi fundado o Fluminense? Que dia foi fundada a Young? Quem é o presidente da Young? Quem é o presidente do Fluminense? Quem é o Massagista?" Cruz credo - relatava Xoxó, lembrando os interrogatórios de perguntas que serviam e seguem servindo como uma espécie de falso júri ritualístico para que uma resposta mal dada sirva de licença a alguns golpes fundamentais ao processo de iniciação. Hoje é "passeio tricolor". Não tem um batom, não tem um ketchup, não tem mostarda, não tem maionese, não tem papel higiênico sujo, não tem mais nada disso. Cara, era demais. "Vai dormir? Tá beleza então, dorme aí, tranquilidade..." Era cruel cara. Sofri pra caralho... Tomar no cu. Nesse momento, o ônibus deu uma nova parada. - Porra, vai parar de novo? O que está acontecendo, ô Barba? Porra, come farinha cara! Minha avó mandava eu comer farinha. Come farinha com maisena e vinagre porra, está com caganeira e toda hora a gente tem que parar!

Parece-me que há um recorrente mecanismo, quase sempre em operação quando se trata de recontar o passado de uma cultura e compará-lo ao presente, que é a tendência inconsciente de intensificar as experiências passadas mais do que de fato foram e enfraquecer as atuais mais do que de fato são. Trata-se, a meu ver, de um saber popular que age a fim de resistir a um tipo de apaziguamento natural de todas as coisas, ou seja, que pela força do absurdo, do exagero, busca lambuzar o presente com aquilo que lhe dá dinamismo, impedindo que o fantasma da morte pelo enfraquecimento, pela inércia, dê fim à cultura. As doses exageradas com que se relatam o que há de raiz é, portanto, o que Ihe serve de húmus, garantindo sua perduração, o que se reflete também nos apelidos, índices dessas radicalidades de raiz que são transferidos por meio desse batismo extraoficial (Passa Fome, Capeta, Pé na Cova). O enigma é esse alimento, e sinto ser inegável o papel do Mal como ingrediente prioritário de tal receita que mantém viva a memória pelo prazer da dor, o que já fora bem indicado em diferentes momentos pelo maldito Nietzsche, como podemos ver nesse trecho:

\begin{abstract}
Quando o homem julgava necessário criar uma memória, isso era acompanhado sempre de sangue, de mártires, de sacrifícios; os mais espantosos holocaustos e os compromissos mais horríveis (como o sacrifício dos primogênitos), as mutilações mais repugnantes (como a castração), os rituais mais cruéis de todos os cultos religiosos (porque todas as religiões foram em última análise sistemas de crueldade), tudo isso tem sua origem naquele instinto que soube descobrir na dor o auxílio mais poderoso da memória. (NIETZSCHE, 2007, p. 59)
\end{abstract}

Seguindo com outros relatos contados nessa mesma viagem pelo mesmo Xoxó, percebemos bem a função similar entre o que havia de violento no relato anterior e no que há de surrealista e escatológico nos próximos.

- Escuta essa, essa virou lenda. Nem me lembro mais em qual viagem foi, mas o Samuel, o Capeta e o Passa Fome desceram do ônibus em uma barraca na 
Dutra e roubaram um porco e um cabrito da senhorinha lá! Cara, olha o absurdo, agora você imagina um porco e um cabrito viajando com a gente em um ônibus já podre de merda do banheiro!

- Outra lenda, pra fechar... Não me lembro bem, mas acho que foi viajando para Campos. Na volta, paramos para fazer um rango, aí já viu, todo mundo roubando comida como sempre e aí me chega a polícia rodoviária, revista todo mundo e não encontra nada. De repente, se escuta aquele grito seco junto com choro, adivinha... Tucano vem carregado pelo colarinho, ele tinha roubado a estátua de uma santa, mas não era qualquer estátua. Era enorme! Era maior do que ele, e ele ainda ficou tentando escondê-la embaixo da camisa! Puta que o pariu, geral mijou nas calças de tanto rir... E detalhe, ele argumentou com o policial que era pra mãe, uma senhora muito religiosa.

Há, portanto, no repugnante, uma ambivalência que lhe confere um papel precioso na comunhão das gentes, justamente pela sua capacidade de pôr em confluência os contrários, de fazer emergir o que há de comum no dicotômico. "Quanto pior, meIhor", "há males que vem para o bem" diz a sabedoria popular. E quanto a isso, a antropologia está também plena de exemplos, como esse relato de Pierre Clastres quanto à jocosidade dos Yanomami.

Os jovens, em particular, adoram os ditos jocosos: "Vem conosco até o pomar. Vamos te enrabar!". Em nossa viagem aos Patanawateri, Hebewe chama um garoto de uns doze anos: "Se me deixares te enrabar, te dou meu fuzil". Todos ao redor dão gargaIhadas. É um gracejo muito comum. Os jovens são muito impiedosos com os visitantes de sua idade. Por algum pretexto, levam-nos até o pomar e ali os dominam para desatar o cordão que prende o pênis, suprema humilha- ção. Brincadeira comum: você dorme inocentemente na rede, quando uma detonação o mergulha numa nuvem nauseabunda. Um índio veio peidar a dois ou três centímetros de seu rosto..." (CLASTRES, 2011, p. 43)

Sobre tal propriedade germinativa e criadora do Mal, que precisa, como vimos, ser tomada em doses vez ou outra exageradas para garantir a perduração de tudo, Jung também já tratou em seus estudos sobre a libido, partindo em determinado momento de uma análise do Fausto de Goethe, como nesse trecho particularmente significativo:

Novamente o diabo entrega a Fausto o instrumento milagroso, assim como no início, aproximando-se de Fausto sob a forma do cão negro, responde à pergunta deste 'Mas quem és tu?', com as palavras:

Uma parte daquela força,

Que sempre quer o mal, e sempre cria o bem. (GOETHE, apud JUNG, 2011, p. 154)

Tal ambivalência que faz do Mal princípio propulsor de tudo, do melhor e do pior, e que o torna, portanto, ingrediente fundamental ao que venho chamando de enigma, traz em si, no sentido aqui proposto, todas as características da junção, incluindo aí até mesmo o seu contrário, o Bem, que nesse jogo é diairético, age inversamente sempre pela cisão, empenhando-se na retirada do Mal de cena, trabalhando na lógica do esclarecimento ideal, contra-enigma portanto. Percepção que encontra amparo nos estudos de Gilbert Durand sobre os regimes diurnos e noturnos do imaginário, no qual o primeiro incluiria os símbolos carregados do sentido da separação, do desgarrar-se do mundo, da ascensão, da transcendência, do enquadramento binário, onde podemos colocar para o nosso estudo, a pulsão esclarecedora, o Bem do colonizador, enquanto o segundo, o noturno, incluiria as 
simbologias de religação, da ambivalência, do mundo em sua complexidade, do descenso, da aceitação de nossa condição mortal, ou seja, o Mal, o dinamismo, o enigma subalterno. Nas palavras de Durand:

Pode-se mesmo dizer que todo o sentido do Regime Diurno do imaginário é pensamento "contra" as trevas, é pensamento contra o semantismo das trevas, da animalidade e da queda, ou seja, contra Cronos, o tempo mortal. [...] Todas as representações e todos os atos são "encarados do ponto de vista da antítese racional do sim ou do não, do bem ou do mal, do útil e do prejudicial..." (DURAND, 2002, p. 188)

E quanto à passagem ao regime noturno do imaginário ele diz:

A representação não pode, sob pena de alienação, permanecer constantemente com as armas prontas em estado de vigilância. O próprio Platão sabe que é necessário descer-se de novo à caverna, tomar em consideração o ato da nossa condição mortal e fazer, tanto quanto pudermos, bom uso do tempo. [...] Enfim, a esquizofrênica tratada por Séchehaye está no caminho da cura quando ganha horror ao exclusivo mundo da iluminação e se religa a um ritual e a um simbolismo noturno. (DURAND, 2002, p. 193)

Portanto, ascende, desliga-se, separa-se, eleva-se, racionaliza-se, mas conforme se avança nessa trajetória, que geralmente crê-se linear rumo à negação do mundo logo esclarecido, em algum momento há a curva de retorno, e é o Mal, o enigma, como elemento primordial do que Durand chama de regime noturno, que assume nessa curva o papel de ponto de convergência, uma espécie de ímã terrestre, um sentido figurado da gravidade, poderíamos dizer, já que não à toa é sobre a simbólica da queda e da descida que Durand vai se dedicar em boa parte de seus estudos. Por fim, estamos mais em encruzilhadas que em vias retas. Levando em conta, então, nosso material empírico, tanto as memórias contadas carregadas de exageros e surrealismos, assim como os momentos de risco vividos, a tensão que já se supõe a quem veste a camisa de uma torcida organizada, as rezas que precedem a saída de suas caravanas e caminhadas, assim como os momentos hipertrofiados de quando estão em grandes aglomerações, são performances em algum grau inconscientes que abrem caminho às sensibilidades desse regime noturno, desse religamento ao mundo, já que provocam excitações comuns ao que de fato está em jogo - doses do enigma na comunhão com o corpo social, com o corpo coletivo, com o todo, numa sociedade colonizada pela lógica fragmentadora da ditadura do esclarecimento racional cuja base de cálculos é o indivíduo autossuficiente. Algo que Jean-Marie Guyau (2008), ao tratar da aceitação de nossa condição mortal como elemento dos prazeres inerentes ao risco, em texto de 1884, chamou de experiência "sublime", na acepção mais ampla e rica do termo, indicando a experiência de entrar em contato com algo grandioso, majestoso, não apenas no comum sentido de elevado, transcendente ou de tudo o que fora expurgado das impurezas. Afastando-se dessa dicotomia, o sentido dado por ele, aceita que há algo de puro no impuro, que há algo de grandioso no que nos antecede e, portanto, há uma excitação "sublime" quando entramos em contato com o que está para além de nós mesmos, o enigma, eu diria, e tudo isso, entendido também como parte integrante de uma "ordem" mais ampla, uma "ordem" cósmica que supõe o caótico, o aspecto menos controlável do sensível, ou seja, uma ordem que sabe bem que logo chegará uma curva do Mal, uma dose de enigma impedindo o aprisionamento do mundo em seu esclare- 
cimento bem calculado, liberando-se da contenção da homogeneização e disparando um "devir-plural".

O perigo encarado por si ou por outro - destemor ou dedicação - não é uma pura negação de si e da vida pessoal: é essa vida mesma levada ao sublime. 0 sublime, na moral como na estética, parece estar sempre em contradição com a ordem, que constitui mais propriamente a beleza; mas isso não passa de uma contradição superficial: o sublime tem as mesmas raízes que o belo, e a intensidade dos sentimentos que ele supõe não exclui uma certa racionalidade interna. (GUYAU, 2008, p. 129) vI $^{\mathrm{V}}$

Ultrapassando, então, as dicotomias, podemos chegar a dizer que está em curso não o fim da racionalidade, mas a emergência de uma outra racionalidade mais do interior, que resgata o sensível como um de seus elementos, mesmo que tenha justamente nessa sua característica, uma predisposição a seguir como que clandestina à maior parte das consciências, mas que segue atuante sob o cinismo da consciência. Precisamente o que Maffesoli relacionou a um "hiper-racionalismo":

...faço referência a Jacob Boehme, que dizia existir "um jogo alegre da eterna geração" capaz de permitir a manutenção de tudo que é / está. Seguir tal pista não é dar provas de irracionalismo; é antes uma espécie de "hiper-racionalismo" à moda de $\mathrm{C}$. Fourier, que integra à análise social parâmetros até então dela comumente excluídos. (1985, p. 35)

Poderíamos, então, seguir trazendo diversas outras memórias de situações paroxísticas como as contadas pelo Xoxó, assim como episódios etnográficos vividos por mim com esses dois últimos, mas para o momento, esses relatos já são suficientes ao que me proponho que é perceber esse vitalismo irradiado tanto no risco vivido quanto na carga dada aos absurdos nessas histórias contadas, como indicativo das sensações corporais, da epifania portanto, que experiências que suspendam de nós mesmos o domínio sobre nós mesmos, ao menos por um tempo, ou seja, que lancem nosso corpo a uma espécie de relaxamento do controle, mergulhando-o numa espécie de espaço análogo a um dinamismo inaugural, originário, que ao mesmo tempo comporta a imanência de nossa morte e de nosso renascimento, é capaz de provocar. Ainda que soe estranho, então, aos ouvidos da humanidade esclarecida e todo o reino por ela erguido, há uma espécie de imperativo estrutural na humanidade que, em muitos momentos, encontrou sociedades mais hábeis em seu manejo melhor equilibrado - a indissociabilidade entre prazer e perda de si, duas dimensões amalgamadas das quais depende a epifania que funda a experiência estética. Relaxado do autocontrole, portanto, o corpo vê diluir-se os cuidados que costuma tomar na sua preservação, suspendendo assim o tempo em sua concepção linear como parâmetro condutor de uma rigorosa economia de si, cujo gestor é a consciência. Nesse estado, o tempo fica sobrepujado ao espaço, restando ao corpo a platitude da presença que, para ser sentida, tateada, apreendida enquanto tal, alarga os poros de todos os sentidos desse corpo, o qual, nessa condição, só pode sentir-se se atravessado, daí o parentesco estreito entre a comunhão e a dor, entre as iniciações de todo tipo e o esgotamento corporal que elas suscitam, entre a morte e o renascimento - o enigma. Nesse sentido, toda experiência estética comporta uma violência, supõe, para acontecer, um corpo desarmadurado, forte porque frágil e por isso bom condutor de sensações. Tal sabedoria, adubo primordial em tantas e tantas sociedades e que thes protegia de qualquer desnutrição por falta de fascínio, no entanto, no reino da humanidade esclarecida moder- 
na, por excelência pequeno-burguesa, ou melhor, usando palavras da molecada que pesquiso, "mongoloides que nunca brigaram na vida", encontra uma dificuldade tão dura quanto sua base epistemológica em render-lhe espaço. Nas palavras de Nietzsche, quando em "O Nascimento da Tragédia" fazia reverência à sabedoria dionisíaca em contrapeso aos homens de segura consciência:

Existem homens que, por falta de experiência ou por estreiteza de espírito, se afastam de semelhantes fenômenos, como se afastam de "doenças contagiosas", e na segura consciência de sua própria saúde os ironiza ou os lamentam. Esses infelizes não suspeitam da palidez cadavérica e do ar de espectro de sua "saúde", quando diante deles passa rugindo a vida ardente dos sonhadores dionisíacos. (2007a, p. 31)

Para desenvolvermos melhor, então, essa sabedoria sacrifical frequentemente convocada quando uma sociedade, comunidade, grupo ou tribo precisam remediar seus laços com a comunhão, quando é preciso reatar o Corpo "Societal" (MAFFESOLI, 2011), será preciso ultrapassar as dimensões limitadas do indivíduo, essa que estamos acostumados a usar como base de reflexão. E para pensar sobre isso, o campo dos estudos da religiosidade parece-me muito profícuo. Por exemplo, percebo em diversos momentos no estudo de Durkheim (1996) sobre a vida religiosa, algumas reflexões que se aproximam desse conceito de força mais ou menos imperativa que intimida a consciência a fim de abrir caminho à coesão de grupo, o que se formos ter como parâmetro o sujeito autônomo filho do iluminismo, será entendido exatamente como no trecho abaixo, como uma sensação de "obrigação", noção que só pode ser utilizada se tratamos de um ser "de consciência". Em todo caso, ao final do trecho, Durkheim mesmo aponta essa incapaci- dade de atribuirmos à análise a categoria da consciência, finalizando a reflexão com uma expressão interessante - uma força "confusamente sentida":

Portanto, se ele se comporta desta ou daquela maneira, [...] não é somente porque as forças que nele residem são em princípio fisicamente temíveis, é porque ele se sente moralmente obrigado a comportar-se assim; tem o sentimento de que obedece a uma espécie de imperativo, de que cumpre um dever. [...] Todos os seres que comungam do mesmo princípio [...] se consideram, por isso, moralmente ligados uns aos outros; têm deveres definidos de assistência mútua, de vendeta, etc., [...] mas não saberíamos dizer até que ponto ela [a força] é expressamente consciente, em que medida, ao contrário, não é apenas implícita e confusamente sentida. (1996, p. 192-193)

Sintetizando, a euforia das situações aqui contadas e de tantas outras desse cotidiano, assim como o interesse por inscrever sensações de alta intensidade física quando se conduz batizados, rituais de iniciação e passagem, parece-me demonstrar bem os efeitos extravagantes desse contato mágico com a força do conjunto, do qual o corpo não pode sair incólume, e abandonando a questão propriamente religiosa, podemos dizer que se trata por fim de uma resultante aparição sensível do enigma, a materialização concreta, enquanto marca no sensível, do que é abstrato, talvez. É nesse sentido, também, que entendo esse outro trecho de Durkheim:

...uma espécie de força anônima e impessoal que se manifesta em cada um desses seres, sem no entanto confundir-se com nenhum deles. Nenhum a possui inteiramente e todos dela participam. Ela é independente dos sujeitos particulares em que se encarna, tanto assim que os precede como sobrevive 
a eles. Os indivíduos morrem; as gerações passam e são substituídas por outras; mas essa força permanece sempre atual, viva e idêntica. (1996, p. 190)

Força que também interessa a Maffesoli e que ele, em certa ocasião, chamou de "saber incorporado", expressão que vai nos auxiliar na proposição desse choque epistemológico definitivo que, a meu ver, esses jovens nos ofertam - aquele que reconhece e devolve ao corpo, sua condição de órgão produtor de saberes, complexificando assim a própria noção moderna de "saberes", uma vez que convoca as dimensões do sensível, da presença, da fisicalidade, à sua elaboração. Dimensões essas que até então precisaram ser interditadas desse processo, a fim de que, desgarrada dessa fonte de incapturas, dessa imanente ginga nunca plenamente capturável que é o corpo, a consciência pudesse triunfar e abrir caminho ao reino da humanidade esclarecida. O maior impedimento da sustentação desse reinado, no entanto, estava no seu próprio interior, ou melhor, em sua própria superfície que mesmo após severas tentativas de separação, seguia ali dando contornos físicos, atribuindo presença a este "ser" que tentava transcender-se por si mesmo, mantendo nele uma terrível gravidade, um enigma que não se deixa esclarecer. $E$ essas juventudes, em meio a tantas outras potências contemporâneas, são eloquentes em exibir desavergonhadas as fissuras indicativas da saturação desse projeto, em sentir-se bem ao nível do chão. Nas palavras de Maffesoli, então:

Existe um "sensus naturae" que sabe, de um saber incorporado, que existe uma força natural responsável por todas as manifestações da vida. Força multiforme, sob muitos aspectos indefinida, algo espontânea, e que escapa às institucionalizações excessivamente rígidas. E que está, igualmente, além e aquém dos enrijecimentos conceituais. (2007, p. 89)
É claro, no entanto, que tais aparições de tal força enigma não se dão a todo tempo de maneira exagerada, como as que privilegiei aqui. Vale destacar, portanto, que mesmo nas manobras mais sutis do dia, mesmo nos gestos mais despretensiosos, ela também está ali comportada, quieta porém operante. Não me parece haver, então, nenhuma ação, mínima que seja, uma piscada de olhos que seja, conduzida absolutamente, em sua totalidade, pelo indivíduo encerrado em si mesmo. Porém, ainda assim, não se pode menosprezar a constante antropológica segundo a qual toda sociedade sempre abriu espaço a alguns eventos extraordinários, justamente a fim de fazer emergir doses mais vigorosas dessa fonte originária que ao mesmo tempo está em todos e não se pode ser apreendida por ninguém. Será então para desenvolvermos melhor essa recorrência das experiências de exagero e sua função, que iremos à superfície primordial de seus efeitos, o corpo e o conceito de epifania como sensação sentida na experiência estética. Nas palavras de Gumbrecht (2010, p. 140), com quem a partir de agora estabelecerei intensa troca, depois de assumida inspiração em Jean-Luc Nancy, epifania trata-se da "sensação [...] de que não conseguimos agarrar os efeitos de presença, de que eles - e, com eles, a simultaneidade da presença e do sentido - são efêmeros".

A epifania, então, disparada sempre por uma experiência estética e portanto inscrita no empírico, ao passo que nos nutre com sensações que recarregam o corpo da sua própria existência e de sua presença, sendo ele ponto de sinergia da experiência vivida, por outro lado, não nos oferece como compensação econômica, algum sentido acabado, esclarecido e livre de equívocos, que possa, através do trabalho intelectual, da "interpretação", preencher com algum "sentido", com algum "esclarecimento", esse vazio deixado 
pela experiência de despossessão de si, oferta que garantiria o imediato processo de reintegração de posse. A "aquisição" do sentido, portanto, que trabalharia feito anestesia no apaziguamento do dinamismo disparado pela epifania, é justamente o que ela esquiva-se em nos oferecer. A experiência estética, então, opera como resistência à lógica de loteamento da racionalidade cognitivo-instrumental, uma vez que, se esta funciona acumulando propriedades de "sentido", a outra funciona mais na lógica do dispêndiovII, cujo efeito por excelência é o corpo extasiado.

Pensando, então, esse corpo moderno assujeitado ao reinado vigoroso do cognitivo, Gumbrecht, em diversos momentos, sustenta uma reflexão muito aproximada daquela noção de "saturação" em Maffesoli:

Aquilo de que, pelo contrário, sentimos falta num mundo tão saturado de sentido e, portanto, aquilo que se transforma num objeto principal de desejo (não totalmente consciente) na nossa cultura - sem surpresa nenhuma, no contexto desse livro, admito (e espero) - são fenômenos e impressões de presença. (GUMBRECHT, 2010, p. 134)

Disso, a partir dessa consagração de uma economia mais dispendiosa que avarenta, podemos caminhar então com a reflexão em torno da íntima proximidade entre a experiência estética, seus efeitos epifânicos, e o "deixar-se" cair em exageros, o que anteriormente fomentou a expressão "toda experiência estética comporta uma violência". Como o uso da palavra "violência" em um sentido de positividade, reconhecendo nela uma função social afirmativa, dispara em nossas mentalidades demasiadamente corrompidas por uma concepção avarenta de si, um alerta, esta acaba por constituir um tabu. Assim então, vale uma parada para desenvolvermos melhor a noção de "vio- lência" como elemento, nas mais variadas doses, necessário ao acontecimento estético, que aqui nos interessa.

... minha principal reação à objeção de que posso estar promovendo a "estetização da violência" é que, se insistíssemos numa definição da estética que excluísse a violência, não só eliminaríamos apenas o aparato de guerra, a destruição de edifícios e os acidentes de tráfego, mas também fenômenos como o futebol americano, o boxe e o ritual da tourada. Permitir a associação da experiência estética à violência, ao contrário, ajuda a compreender por que certos fenômenos e eventos se nos revelam tão irresistivelmente fascinantes - embora saibamos que, pelo menos em alguns desses casos, essa "beleza" segue junto da destruição de vidas. (GUMBRECHT, 2010, p. 144-145)

Em primeiro lugar, é preciso desassociar o reconhecimento da dimensão estética da violência, de uma logo automática legitimação ética de qualquer ato violento, da qual sei corro o risco de ser acusado, ainda que não seja o caso. Em outras palavras, a sensação de epifania não é regida por réguas morais que, graduadas do Mal ao Bem, condicionem seu acontecimento somente ao avanço em direção à última extremidade. Não por acaso, é comum que a intensidade de uma epifania venha de maneira ambígua acompanhada de um repúdio, como o que podemos ter diante da imagem de uma cidade bombardeada, ou de um lamento revoltado quando testemunhamos um assassinato. Em todo caso, a função catártica que o assassínio, como tema principal no teatro antigo, na tragédia grega, teve no elevado enlaçamento empático do corpo de todos os envolvidos na cena, impedindo inclusive que utilizemos as categorias cindidas de "personagem" e "espectador" para compreendê-la, as- 
sim como a alta expectativa e audiência que capítulos de novelas contemporâneas alcançam quando da morte de algum de seus personagens, dão sinais de que essa relação indissociável entre epifania, catarse, experiência estética, comunhão e sacrifício violento, segue como um eco arcaico muito presente. Nesse sentido, não é surpreendente que o espectador popular, mesmo hoje, ainda interponha o ator televisivo quando o encontra na rua, no mercado, no shopping, chame-o pelo nome do personagem e cobre dele com autoridade, uma outra postura "na novela", lançando sobre o corpo dele, inclusive, os humores da paixão, seja de raiva ou de amor. Algo de parentesco próximo ao funcionamento do coro na tragédia grega descrito por Nietzsche, assim como do teatro na Idade Média citado por Gumbrecht, atitudes que aos olhos do homem esclarecidamente civilizado só podem ser frutos de uma ingenuidade lamentável:

De fato, tínhamos sempre pensado que o verdadeiro espectador, fosse quem fosse, devia ter sempre plena consciência que é uma obra de arte que está diante dele e não uma realidade empírica, enquanto o coro trágico dos gregos é necessariamente obrigado a reconhecer, nas personagens em cena, seres que existem materialmente. $\mathrm{O}$ coro das Oceânides crê verdadeiramente ver diante de si o titã Prometeu e se considera tão real como considera real o deus que está em cena. (NIETZSCHE, 2007a, p. 58)

A copresença de atores e espectadores na cultura medieval parece ter sido uma copresença "real", na qual não se excluía o contato físico mútuo - de fato, esse contato era tão pouco excluído, que os espectadores das representações da Paixão no final da Idade Média chegavam a "executar" o corpo do ator que representava Cristo, apedrejando-o. (GUMBRECHT, 2010, p. 54)
Sendo assim, a "desmedida", o "êxtase", para usarmos termos que estarão no próximo trecho também retirado de Nietzsche em "O Nascimento da Tragédia", são dimensões que não se alcançam por meio da reflexão, do pensamento, mas sim pela experiência estética, portanto são também elementos protagonistas nos sazonais cuidados a que se dedicam comunidades com mito, a fim de evitar a ameaça da plena individuação, contra a qual a "desmedida", o "êxtase", o sacrifício, portanto, são frequentemente convocados a atuar.

O indivíduo, com toda a sua ponderação e sua medida, submergiu no esquecimento de si do estado dionisíaco e esqueceu os preceitos apolíneos. A desmedida se revelou verdade; a contradição, o êxtase nascido da dor falava espontaneamente de si, do coração da natureza. (NIETZSCHE, 2007a, p. 45-46)

Se, então, é de experiências que lancem o corpo em gestos, movimentos, comportamentos, linguagens, expressões, reconhecidamente movidas não exclusivamente pela sua dimensão dirigida, mas por algo para além e para aquém de si mesmo; se é um corpo (des)possuído, então, que é convocado a suspender a memória de si para performatizar a memória coletiva ${ }^{\mathrm{VIII}}$, de grupo, da tribo; se esse corpo trágico, então, é levado a periodicamente perder-se, morrer e renascer, logo, será justamente de mecanismos de "violência", numa acepção do atravessamento de nossa subjetividade, da dinamização de nossa inércia pessoal, que os exageros necessários serão construídos. Em todo caso, por "exagero", ou por "violência", não se pode compreender apenas suas versões hipertrofiadas, como as que naturalmente parecem estar mais destacadas neste artigo, mas também as hipo que ao revés, geralmente por privações, também rompem com a "vida bem calculada" moderna, como 
os jejuns, os isolamentos monásticos, o virtuoso combate que as meditações de diversos tipos impõem à emersão de qualquer pensamento, tudo isso também, operando repressões ao reinado do si mesmo esclarecido. "Afinal, há muito a experiência estética tem sido associada a acolher o risco de perder o domínio sobre nós mesmos - pelo menos por algum tempo"(GUMBRECHT, 2010, p. 145).

Repressões de si podem encontrar catalizações de diversos tipos e diferentes intensidades, ou seja, voltando ao nosso cotidiano, não é preciso estar disposto a frequentar assiduamente situações de briga para que o imaginário sedimentado a partir delas, encontre na sua subjetividade uma recepção prazerosa. Os combates irradiam e os efeitos de contágio próprios desses exageros podem ser percebidos nessa franca fala do Bozo, membro da bateria da Young Flu:

Cara, eu nunca gostei de briga, sei lá, não faz parte de mim, sempre fui mais calmo. Mas por outro lado, eu gostava de ouvir que a Young colocou alguma outra torcida para correr, eu me amarrava em ficar sabendo. Também sempre gostei do "Duende Verde", tenho vários adesivos, desenhos de bandeiras, tudo guardado. E de qualquer maneira, é um monstro, é Mal, né? (Bozo em entrevista realizada em abril de 2013)

Assim como em Paris, enquanto aguardávamos a chegada dos ônibus para a caravana que nos levaria à Toulouse para assistir ao jogo do PSG contra o time da casa, chegou a notícia de que um grupo de torcedores do próprio PSG, mas, no entanto, rivais tradicionais daquele grupo com quem eu estava, também viajariam e em maior número do que "nós". Diante disso, David, que eu sabia "não era de briga" e já havia me confessado que não gostava disso, virou-se para mim e disse:
- Hoje estou com uma vontade de dar uns chutes em alguém. - disse encenando no ar a mímica de um chute que, pelo que percebi, simulava atingir alguém que já estivesse no chão.

Em um soco, em um abraço, em um canto, em um bonde que marcha pulando e soltando morteiros, em uma camisa, em uma história absurda, por todo lado o enigma, o todo, o corpo societal circula e acimenta uns aos outros. Seja vivendo com mais frequência esses exageros, seja sendo atingido de maneira mais sutil por essas irradiações dos seus prazeres, ou mesmo quando se chora a morte de um amigo, ou ainda se comemora meio friamente a morte de um rival, o que é inegável é o papel fundante do Mal no erguimento e na perduração do todo. É nesse sentido, então, que em nossa época, ao que se chama mais ou menos provisoriamente de pós-modernidade, como aponta bem o trecho seguinte de Maffesoli, estaria em curso esse retorno do Mal, do Mito, algo ao mesmo tempo revigorante e destrutivo. Em uma palavra, uma época de "crise".

Nunca será demais insistir nessa forte característica da pós-modernidade: a reafirmação dos fatores impessoais exatamente onde, numa perspectiva de horizonte curto, os observadores sociais, limitam-se a recitar a ladainha do individualismo. Com efeito, o desejo do grupo, aquilo que chamamos de ideal comunitário, é uma tendência de fundo. [...] Um vitalismo que temos dificuldade de levar em conta porque comporta, logicamente, um certo excesso. A vida e o gasto estão intimamente ligados. $\mathrm{E}$, como observa $\mathrm{V}$. Jankélévitch, referindo-se a Guyau e a Simmel, o próprio da vida é provir de um impulso "semi-inconsciente, de uma pulsão instintiva originária das profundezas escuras". (MAFFESOLI, 2007, p. 82-83) 


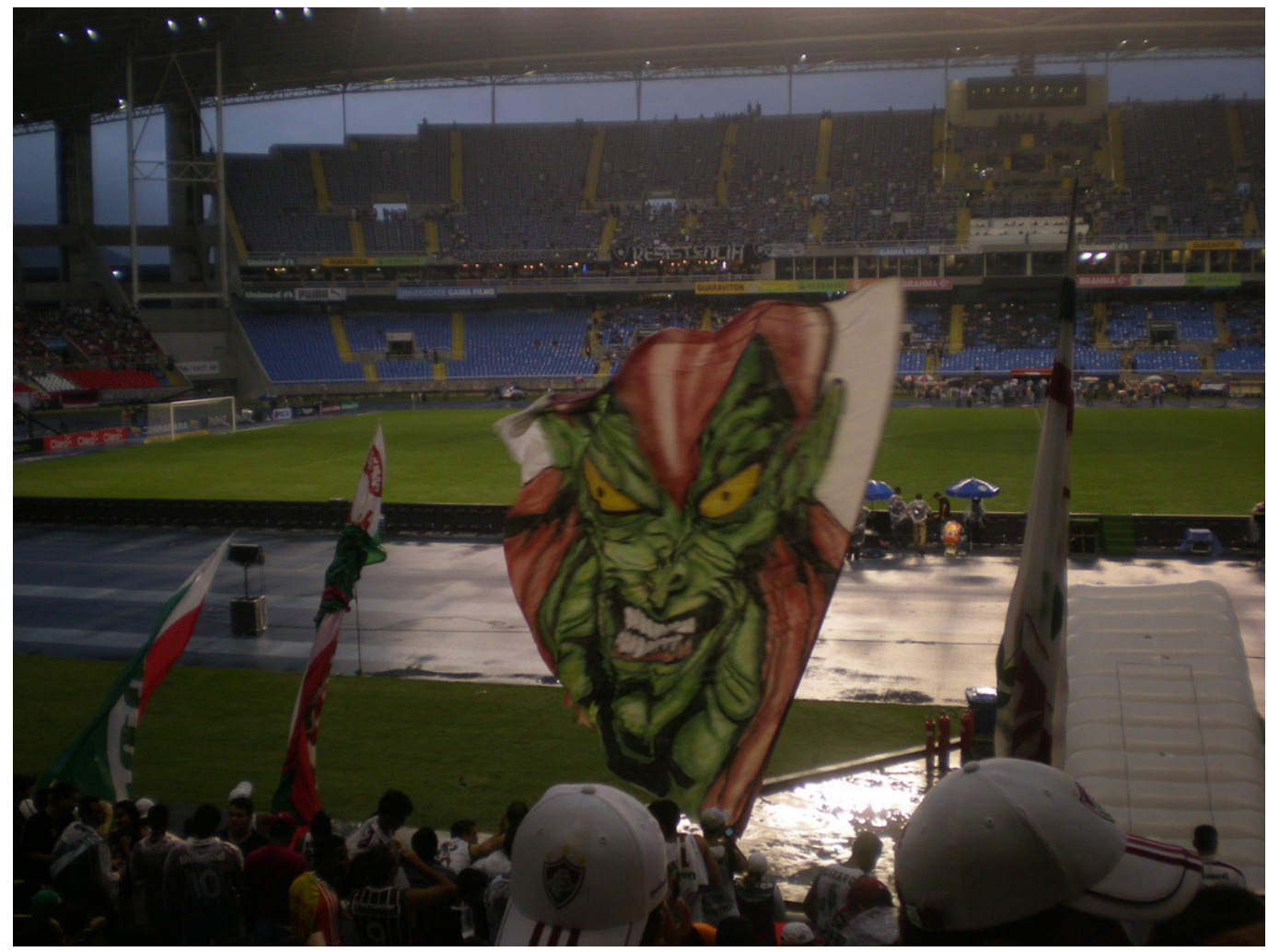

Figura 2: Bandeira do Duende Verde

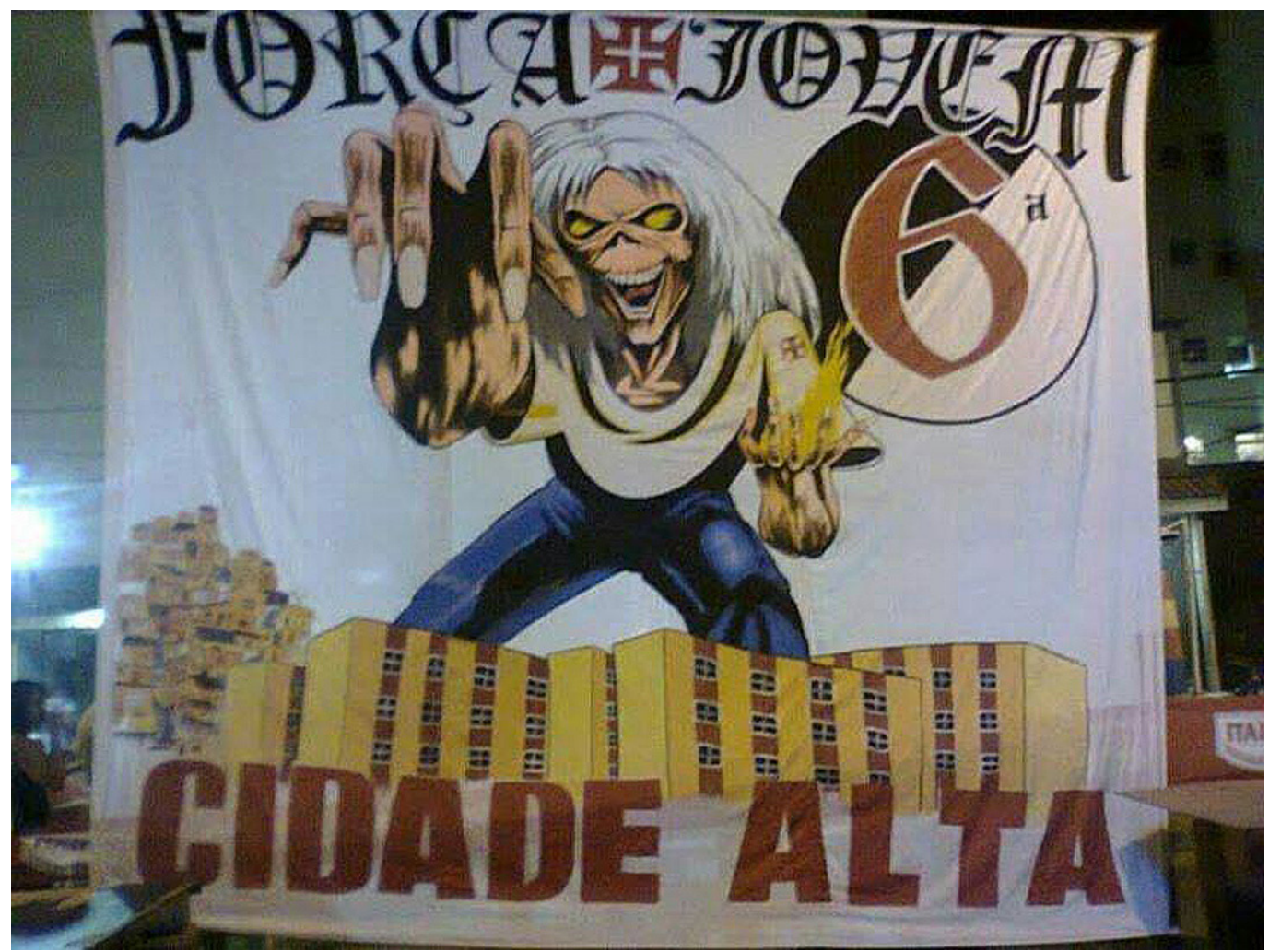

Figura 3: Bandeira da Força Jovem do Vasco com o Eddie 
Da mesma maneira, alguns símbolos que tais sociedades ou grupos sintetizam e que passam a lhes servir de ícone representativo, são carregados dessas mesmas características. Em nosso caso, por exemplo, a presença quase unânime de motivos monstruosos e bélicos na elaboração dos símbolos de cada torcida organizada, como o Duende Verde de boca aberta e dentes afiados no caso da Young Flu, o Eddie, morto-vivo da Força Jovem do Vasco, o Tazmania da Bamor do Bahia, o canhão de três canos da Torcida Jovem do Flamengo, a caveira da morte da Torcida Jovem do Botafogo, utilizada em desenho semelhante pela Torcida Os Fanáticos do Atlético Paranaense, a própria morte com sua foice da Fúria Indepen- dente do Paraná e da Comando VermeIho do CRB de Alagoas, assim como a recorrência de animas em formas antropomórficas como o urubu musculoso da Raça Rubro-Negra e da Cearamor, o cachorro bravo da Fúria Jovem do Botafogo, o leão tanto da Torcida Jovem do Sport como da Torcida Uniformizada do Fortaleza, o rato da Torcida Jovem Fanautico, o macaco da Camisa 12 do Internacional, o galo da Galoucura do Atlético Mineiro e da Torcida Jovem do Galo do Treze de Campina Grande, a cobra coral armada com duas metralhadoras da Torcida Inferno Coral do Santa Cruz, o dragão da Torcida Trovão Azul do Confiança de Sergipe, o touro negro da Torcida Falange Tricolor do Fluminense de Feira de Santana, entre outras.

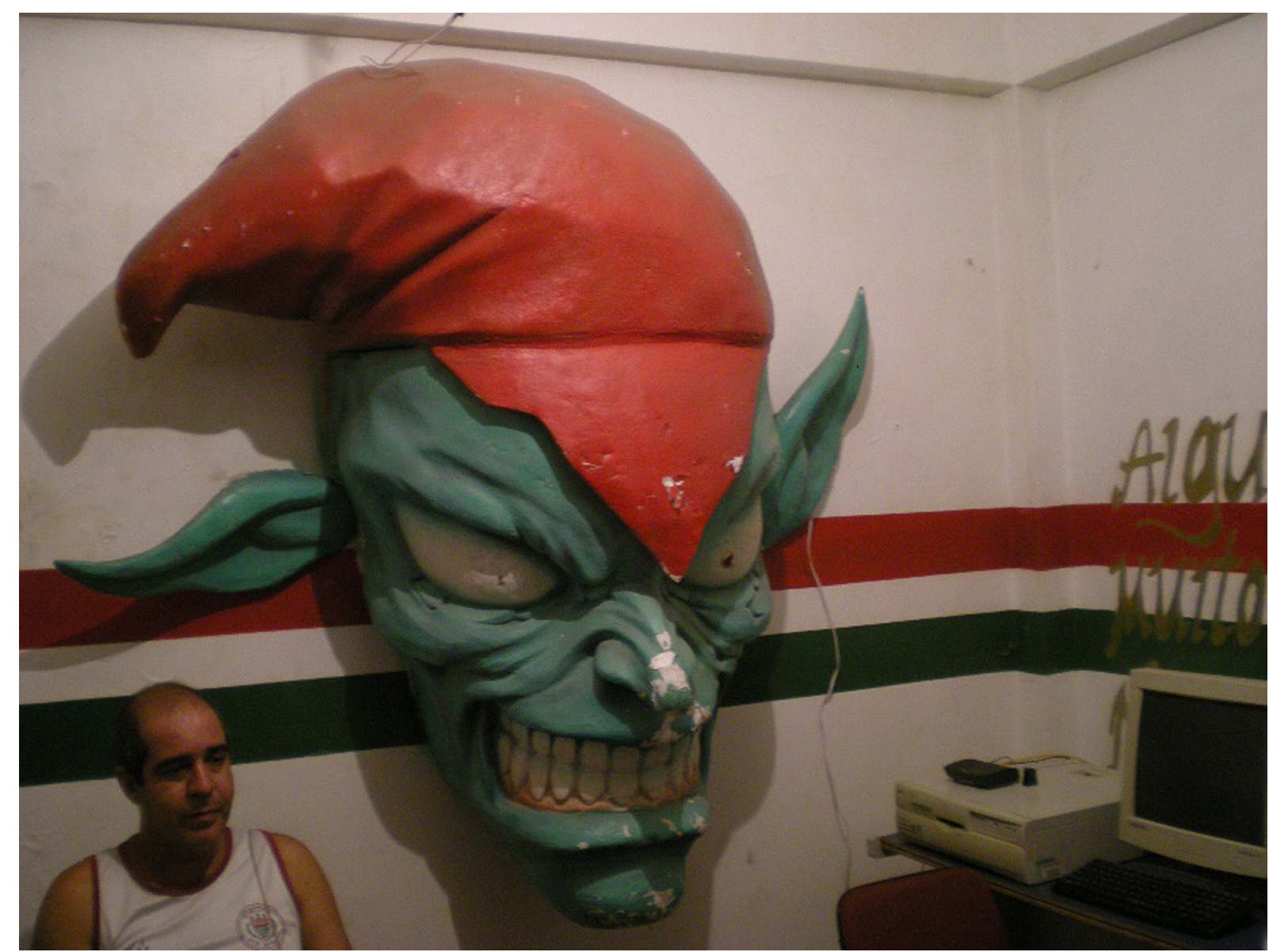

Figura 4: Cabeça do Duende Verde na sede da Young Flu 


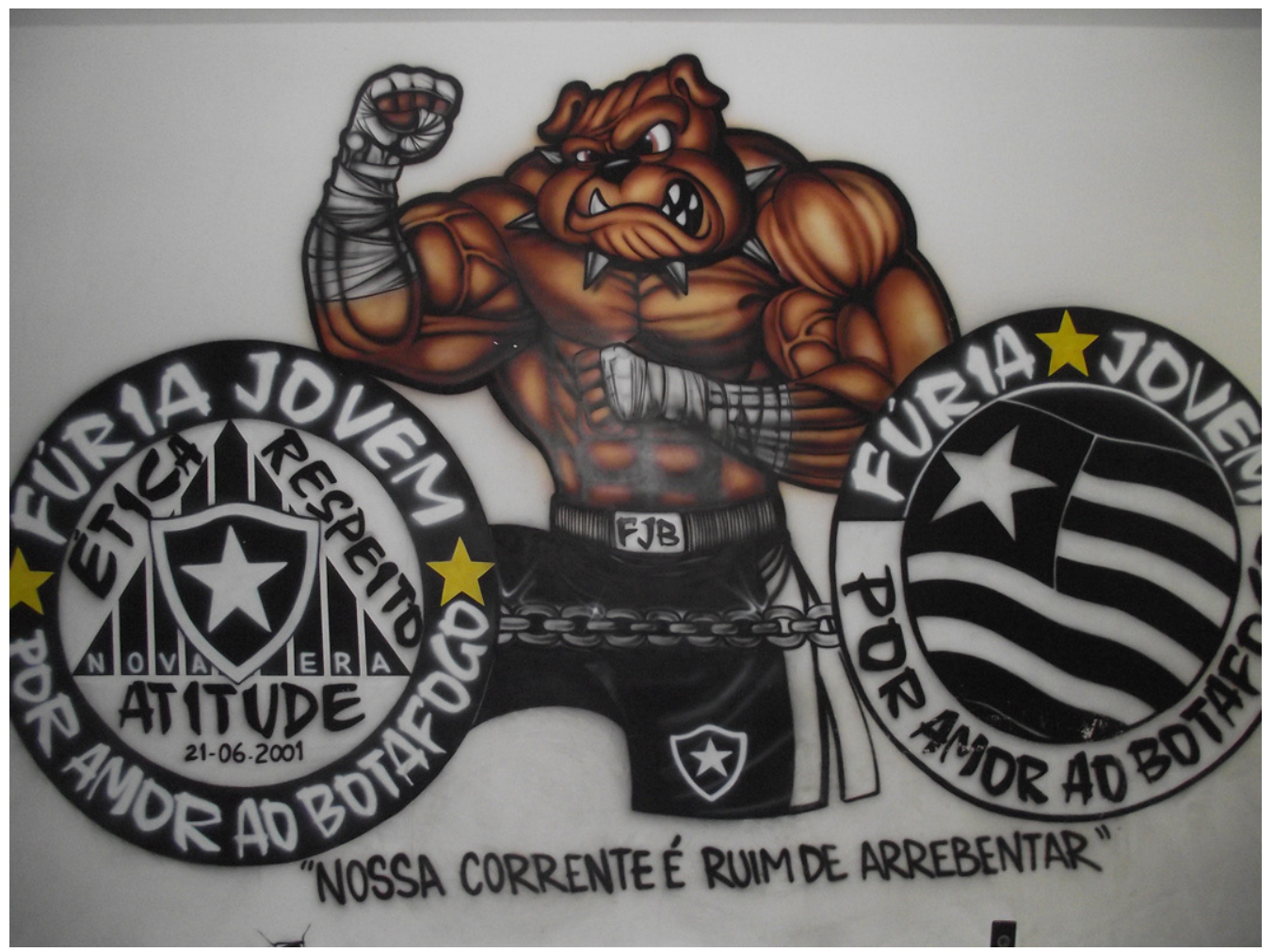

Figura 5: Cachorro da Fúria Jovem do Botafogo

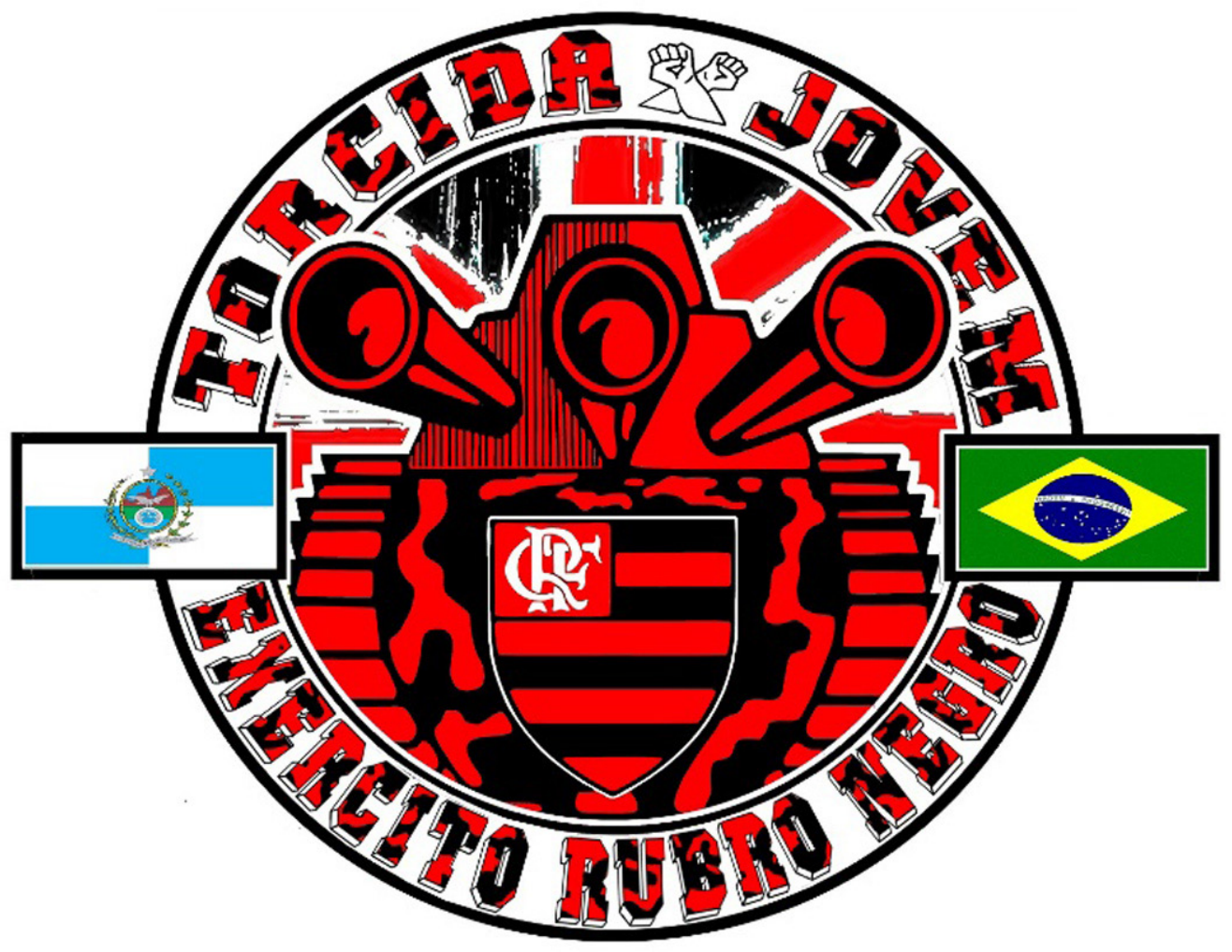

Figura 6: Tanque da Torcida Jovem Fla 
Todas são imagens que carregam em si o tema da morte, ou ao menos da imanência dela, sendo a frequência de dentes, bocas, garras afiadas e a foice, portanto, instrumentos de corte, de trinca, indicativos de uma morte por dilaceramento, figura ambivalente do imaginário que por ser recorrente em uma série de imagens arquetípicas de contornos variados em diversas narrativas míticas, ocupou um bom pedaço dos estudos de Durand (2002, p. 84), para quem, "na maior parte dos casos, a animalidade, depois de ter sido o símbolo da agitação e da mudança, assume mais simplesmente o simbolismo da agressividade, da crueldade". Mais adiante, ele ainda reafirma: "o animal é assim, de fato, o que agita, o que foge e que não podemos apanhar, mas é também o que devora, o que rói" (DURAND, 2002, p. 90). E indo mais especificamente para a boca e em alguns casos o bico, e aqui guardamos associação também à lâmina da foice e às garras também frequentemente protuberantes, Durand diz:

... é assim a boca que passa a simbolizar toda a animalidade, que se torna o arquétipo devorador [...]. Reparemos bem num aspecto essencial desse simbolismo: trata-se exclusivamente da boca armada com dentes acerados, pronta a triturar e a morder, e não da simples boca que engole e que chupa que [...] é a exata inversão do presente arquétipo. [...] É, portanto, na goela do animal que se vêm concentrar todos os fantasmas terrificantes da animalidade: agitação, mastigação agressiva, grunhidos e rugidos sinistros. (2002, p. $84-85$ )

Aqui, cabe, então, deixarmos marcado esse dinamismo próprio de toda monstruosidade, essa figura que dá contornos extravagantes ao caos originário que precede toda criação, logo, sendo todo monstro, portador de um "devir-dionisíaco" embaralhador das cartas, ato que antecede o recomeço do jogo. Não, por acaso, então, trata-se de uma figura mítica que por toda parte ativa as preocupações em sua domação, imanência de todo devir pré-remodelagem, por isso um "agitador" milenar, do qual poucas vezes a humanidade igualou o sentido do seu possível domínio ou morte após dura batalha, com a plena e definitiva anulação de sua potência. É recorrente, nesse sentido, portanto, que a monstruosidade carregue em si uma espécie de predisposição a múltiplos renascimentos, uma eternidade pautada em sucessivas mortes, como é o próprio caso do Duende Verde utilizado pela Young Flu que, originado da história em quadrinhos do Homem-Aranha, é um de seus vilões mais poderosos, reaparecendo sempre, mesmo após ter sido dado como morto, algo próximo das figuras de "morto-vivo", como o Eddie e a própria Morte com a Foice, que dá à morte a condição de vivente, de movente e não a inércia na qual se assenta boa parte das paranoias modernas com a morte finda. Sendo assim, então, todo monstro potencialmente eterno porque morre muitas vezes, não é surpreendente que haja nele também uma dimensão divina, como apontaram Mauss e Hubert no célebre estudo sobre o sacrifício, mais precisamente no capítulo dedicado ao sacrifício do deus, a partir de uma longa lista de combates mitológicos entre um deus e um monstro, embate que flagra também uma ambivalência, a divindade atribuída também ao monstro.

É uma diferenciação de outro tipo que se devem os mitos cujo episódio central é o combate de um deus com um monstro ou com um outro deus. Tais são, na mitologia babilônia, os combates de Marduk com Tiamat, isto é, o Caos; de Perseu matando a Górdona ou o dragão de Joppe, de Belerofonte lutando contra a Quimera, de São Jorge vencedor do Dadjdjal; é também o caso dos trabalhos de Hércules e, 
enfim, de todas as teomaquias; pois nesses combates o vencido é tão divino quanto o vencedor. (MAUSS; HUBERT, 2013, p. 93)

Nesse caso, no lugar do simples triunfo do Bem contra o Mal, que somos hoje levados a usar como principal forma de interpretação desses eventos, os autores apresentam na sequência a frequência com que, logo depois, o vitorioso, consternado com o fim do vencido, também morre - "para completar a prova da equivalência desses temas, digamos que sucede muitas vezes de o deus morrer após sua vitória" (MAUSS; HUBERT, 2013, p. 94). Mauss e Hubert nos oferecem assim uma concepção mais trágica, atribuindo ao monstro e ao deus, a condição de serem "desdobramentos do mesmo gênio", figuras resultantes do afastamento duplo diante do qual, a batalha não é a consagração da divisão, como somos acostumados a encarar a partir de nossa concepção belicista do tipo aniquilante, norma para o homem esclarecido, mas sim, a própria ocasião do reencontro; os golpes aqui, a falta de exemplos de um covarde "correr da luta", assentam-se mais numa vontade epifânica, portanto efêmera, porém frequente, de reunião dos contrários.

Essas equivalências e alternâncias se explicam facilmente se considerarmos que os adversários confrontados com o tema do combate são o produto do desdobramento de um mesmo gênio. A origem dos mitos desse tipo foi geralmente esquecida; eles são apresentados como combates meteorológicos entre os deuses da luz e das trevas ou do abismo, entre os deuses do céu e do inferno. Mas é extremamente difícil distinguir com clareza o caráter de cada um dos combatentes. São seres de mesma natureza cuja diferenciação, acidental e instável, pertence à imaginação religiosa. (MAUSS; HUBERT, 2013, p. 94)

Nesse mesmo sentido, é interessante notar que em episódios mais tardios, o Duende Verde também se apossa do Homem-Aranha e o deixa psiquicamente confuso quanto à sua identidade. Por ora, retomemos Durand e a ambivalência da boca, para concluirmos essa íntima proximidade das categorias boca, dentes, morte e renascimento. Se a boca e analogamente as garras são, juntas, forças de dilaceração, de destruição, símbolos que segundo a psicanálise, como aponta o próprio Durand, estão relacionados à sensação de incompletude, o engolimento, o ventre e a digestão formam um sistema onde esses pedaços são reatados, se reacomodam, se reembaralham e de onde podem voltar renascidos, como aponta o trecho abaixo:

O engolimento não deteriora, muitas vezes mesmo valoriza ou sacraliza. "O engolido não sofre uma verdadeira desgraça, não é necessariamente vítima de um acontecimento infeliz. Mantém um valor." $O$ engolimento conserva o herói que foi engolido. (2002, p. 206)

Em resumo, portanto, a partir da costura entre alguns materiais etnográficos e determinada plataforma teórica, este artigo sugere que universos jovens e populares de nossas cidades, como é o caso das torcidas organizadas neste nosso artigo, apesar de serem constantemente reduzidos sob a máquina do discurso determinante e criminalizador, podemguardar em seus cotidianos, ricos reservatórios de formas de viver, de imagens, de narrativas, de rituais, de saberes, de epifanias que operam como "tecnologias" encantadas na defesa e garantia cotidiana da manutenção de uma zona subjetiva que celebra o indeterminado, o enigma, em contrapeso ao fantasma da imobilização pela determinação racionalista, esclarecida. 


\section{Bibliografia}

BATAILLE, Georges. A parte maldita, precedida de "A noção de dispêndio". Belo Horizonte: Autêntica, [1949] 2013.

CLASTRES, Pierre. Arqueologia da violência pesquisas da antropologia política. São Paulo: Cosac Naify, [1980] 2011.

DURAND, Gilbert. As estruturas antropológicas do imaginário: introdução à arquetipologia geral. 3. ed. São Paulo: Martins Fontes, [1992] 2002.

DURKHEIM, Émilie. As formas elementares da vida religiosa: o sistema totêmico da Austrália. São Paulo: Martins Fontes, [1912] 1996.

GUMBRECHT, Hans Ulrich. Produção de presença: o que o sentido não consegue transmitir. Rio de Janeiro: Contraponto, Ed. PUC-Rio, [2004] 2010.

GUYAU, Jean-Marie. Esquisse d'une morale sans obligation ni sanction. Paris, Allia.[1884] 2008.

HEIDEGGER, Martin. A origem da obra de arte. São Paulo, Edições 70, [1977] 2010.

JUNG, Carl Gustav. Símbolos da transformação: análise dos prelúdios de uma esquizofrenia. 7. ed. Petrópolis: Vozes, [1952] 2011.

MAFFESOLI, Michel. A sombra de Dionísio: contribuição a uma sociologia da orgia. Rio de Janeiro: Edições Graal, 1985.

MAFFESOLI, Michel. Quem é Michel Maffesoli: entrevistas com Christophe Bourseille. Petrópolis: De Petrus et Alii, 2011.

MAFFESOLI, Michel. O ritmo da vida: variações sobre o imaginário pós-moderno. Rio de Janeiro: Record, 2007.

MAUSS, Marcel; HUBERT, Henri. Sobre o sacriffcio. São Paulo: Cosac Naify, [1899], 2013.

NIETZSCHE, Friedrich. A genealogia da moral. São Paulo: Escala, [1887] 2007.

NIETZSCHE, Friedrich. O nascimento da tragédia. São Paulo: Escala, [1872], 2007a.

SANTOS, Boaventura de Sousa. Para um novo senso comum: a ciência, o direito e a política na transição paradigmática. Vol. 1. A crítica da ra- zão indolente: contra o desperdício da experiência. São Paulo: Cortez, 2011.

SIMMEL, Georg. Sociologie: Études sur les formes de la socialisation. 1er édition. Paris: Quadrige, [1908] 2010.

\section{Recebido em 10/03/2017 \\ Aprovado em 15/03/2017}

I Doutor em Educação pelo ProPEdUERJ. Professor da Faculdade de Educação da Universidade do Estado do Rio de Janeiro (UERJ), Brasil. Contato: coelhoguga@ gmail.com.

II Bairro da Zona Oeste do Rio de Janeiro.

III Todas as citações dessa obra foram feitas com tradução livre a partir da edição francesa.

IV Durante o estágio doutoral em modalidade sanduíche na Université Paris V - Sorbonne sob supervisão do professor Michel Maffesoli.

V Para lançar mão de uma expressão do vocabulário desses jovens.

VI Todas as citações dessa obra foram feitas com tradução livre a partir da edição francesa.

VII Ver Bataille, A noção de dispêndio (2013).

VIII Não por acaso, é sabida a falta de memória que resta ao corpo do (des)possuído após os mais variados rituais que preveem possessão. 